\title{
42. PLEISTOCENE DIATOMS FROM SITE 262, LEG 27, DSDP
}

\author{
Anastasia P. Jouse and Galina H. Kazarina, Institute of Oceanology, Academy of Sciences of the USSR, Moscow
}

Site 262 is located near the axis of the Timor Trough, $75 \mathrm{~km}$ south of the western tip of Timor and $230 \mathrm{~km}$ northeast of the Ashmore Reef. The water depth at this site is 2315 meters.

The cored sediments are chiefly nanno oozes with some terrigenous material. Forty-four samples were selected for diatom analysis, generally one or two samples per core. Other samples from each of the 47 cores recovered were checked under the microscope.

Diatoms are present only in the upper 27 cores. They are not numerous in most samples which is probably due to dilution by terrigenous and carbonate material. However, the recovered diatoms are well preserved and easily determined, and they are sufficiently abundant to characterize the diatom flora wherever present.

\section{METHODS}

The material was treated in accordance with standard procedures used in the Laboratory of Micropaleontology, Department of Ocean Geology, Institute of Oceanology, Academy of Sciences, USSR. The method is as follows: $0.5 \mathrm{~g}$ of sediment is heated in a $10 \%$ $\mathrm{Na}_{5} \mathrm{P}_{3} \mathrm{O}_{10}$ solution, then boiled for 60 minutes in a $30 \%$ $\mathrm{H}_{2} \mathrm{O}_{2}$ solution. During the next 5-6 days samples are washed in distilled water to remove tripolyphosphate and particles of pelite. The sediments are then treated with $10 \% \mathrm{HCl}$ to remove carbonate material. Finally, the sample is washed and a portion of the material is mounted under a cover glass and examined under the microscope. This procedure allows calculation of the number of diatom valves per $\mathrm{g}$ of sediment.

In determining the diatom content of the sediment such species as Ethmodiscus rex, Thalassiotrix sp., Thalassionema sp., and Chaetoceros sp. were ignored because they generally occur only as fragments. The absolute abundance of diatoms is thus somewhat understated. The relative abundance of each species is expressed as a percentage of the total number of diatoms.

A list of the 97 recognized diatom species from Site 262 and their relative abundances in each sample is given in Table 1. The abundance and distribution of the most typical and numerous species are shown on Figure 1. Plates 1 through 7 are SEM photographs of some diatom species from this site and of typical species of the equatorial-tropical area of the Indian Ocean.

\section{DISTRIBUTION OF DIATOMS}

Figure 1 shows that the diatom content of the sediments varies significantly in the upper part of the section (Cores 1-27). The maximum diatom concentration observed-9,099,200 valves/g-is in Core 6, Section 6; the minimum concentration of 720,000 valves/g is in Core 23, Section 3. The sediments have an average concentration of about 2,500,000 valves/g which is relatively small compared to the number of diatoms in the surface sedimentary layer in adjacent parts of the Indian Ocean (Kozlova, 1969). The lower value at Site 262 is due to high dilution by carbonate material. On the whole, the diatom content of the sediments at Site 262 increases upward from Core 27. Cores 12 and 26, however, contain only sparse diatoms.

Remnants of siliceous organisms in the studied sediments are diatoms, silicoflagellates, Radiolaria, and sponge spicules; neither the diatoms nor the other groups are numerous.

\section{SPECIES CHARACTERISTICS OF DIATOMS}

Ninety-seven species of diatoms have been recognized in the sediments of Site 262. The overwhelming majority of them (38) are oceanic species. Neritic species are considerably less abundant (10) and some sublittoral species occur in the sediments as single specimens. Some of the observed diatoms could not be determined specifically.

Predominant among the oceanic species are Asteromphalus arachne, Coscinodiscus nodulifer. Hemidiscus cuneiformis, Hitzschia marina, Planktoniella sol, Pseudoeunotia doliolus, Rhizosolenia alata, $R h$. bergonii, Rh. styliformis, Roperia tesselata, Thalassionema nitzschiodes, Thalassiosira oestrupii. All of the diatom-bearing samples are characterized by the presence of more or less numerous specimens of the oceanic species Thalassionema, Thalassiotrix, and Chaetoceros, represented mainly by spores and bristles.

Among the neritic species one can distinguish Actinoptychus bipunctatus, A. undulatus, Nitzschia bicapitata. $N$. interrupta, $N$. longicollum, and Thalassiosira decipiens. The most significant sublittoral species are Actinocyclus ehrenbergii. Diploneis bombus, Cyclotella striata. Grammatophora marina, Melosira sulcata, and Pleirosigma angulatum.

Typical diatom species that make up a considerable portion of the total percentage are Actinocyclus ehrenhergi. Coscinodiscus nodulifer. Cyclotella striata, Nitzschia marina, Planktoniella sol, Pseudoeunotia doliolus, Rhizosolenia bergonii, Thalassionema nitzschioides, T. nitzschioides var. parva, Thalassiosira decipiens, and $T$. oestrupii.

Figure I shows the distributions of the species expressed in percentage of total number of diatoms. The distribution of the species Thalassiotrix is expressed as abundant, common, few, and rare.

On the basis of quantitative and qualitative variations of the diatom flora the upper part of the section at Site 262 can be divided into 5 zones:

Zone I - Cores I-1]

Zone II-Core 12, Sections 3, 6

Upper Pleistocene 
TABLE 1

Percent of Total Number of Diatoms

\begin{tabular}{|c|c|c|c|c|c|c|c|c|c|c|c|c|c|c|c|c|c|c|c|c|c|c|c|c|c|c|c|c|c|c|c|c|c|c|c|c|c|c|}
\hline $\begin{array}{c}\text { Sample } \\
\text { (Interval in cm) }\end{array}$ & & & & & & & 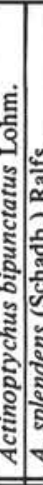 & 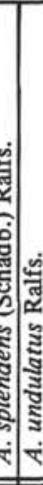 & 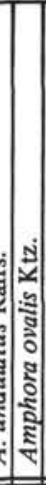 & ฐั & 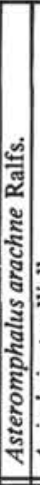 & & 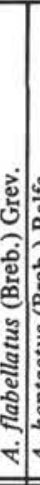 & 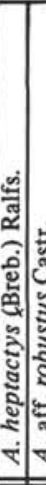 & 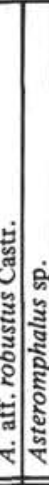 & 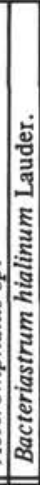 & 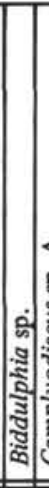 & 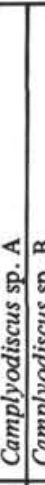 & 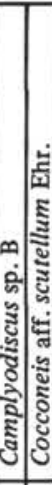 & 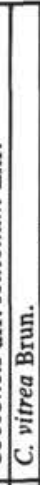 & 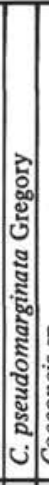 & 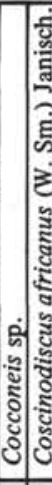 & 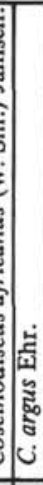 & 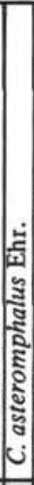 & 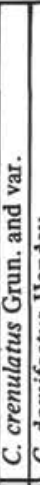 & 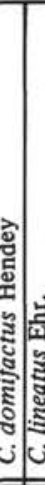 & 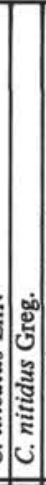 & 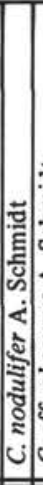 & 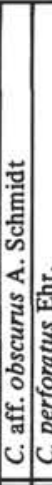 & 3 & & 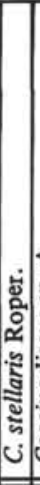 & 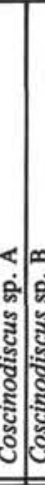 & 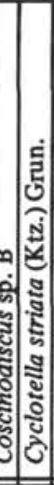 & & 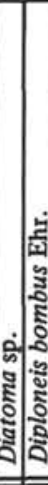 & & 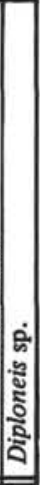 \\
\hline & & & & & & & + & $-1+$ & - & + & & & & -1 & $-1+$ & + & -7 & - & $-1-$ & & -1 & $1+$ & 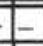 & & 2 & -3 & & 6 & $-1-$ & -1 & & - & -1 & $1-$ & 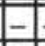 & + & 3 & \\
\hline & & & & & & & & & - & & & & & - & - & 4 & - & -- & $-1-$ & & - & -1 & & 1 & 2 & -1 & & 1 & -2 & $2-$ & 2 & + & -1 & \begin{tabular}{ll|}
1 & 5 \\
\end{tabular} & & 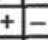 & & + \\
\hline & & & & & & & & 2 & + & & & & - & - & $-1-$ & 5 & 2 & -1 & $-1-$ & & + & -+ & & + & + & + & - & 4 & -1 & $1-$ & - & + & -2 & $2+$ & - & $7=$ & & - \\
\hline & & & & + & & & + & 1 & $1-$ & + & -1 & + & + & - & $-1-$ & 4 & 2 & -1 & - & & + & -1 & + & - & 4 & -1 & - & 1 & -1 & $1-$ & - & -1 & $-1+$ & +1 & - & $E$ & + & + \\
\hline & 0 & & + & -1 & 5 & & \begin{tabular}{l|l}
2 & 1 \\
\end{tabular} & $1-$ & -1 & - & 1 & T & - & - & ++ & 5 & - & -1 & -1 & $=$ & - & -2 & + & - & + & -1 & - & 11 & $-1-$ & -1 & + & - & $-1+$ & +3 & - & Z & & + \\
\hline & & & + & & +1 & + & & -1 & $=$ & - & \begin{tabular}{|l|}
3 \\
\end{tabular} & - & - & - & -1 & 5 & - & - & $-1-$ & - & - & -+ & - & - & 1 & + & & 5 & -1 & - & 1 & -1 & - & -6 & - & Z & - & + \\
\hline & & & & -1 & $1+$ & + & & $-\sqrt{2}$ & 2 & -1 & + & -1 & - & -1 & $-1+$ & 10 & -1 & -1 & $-1+$ & 1 & - & -1 & + & - & 1 & $2-$ & -1 & 2 & $-1-$ & $1-$ & + & -1 & + & -2 & - & $E$ & -1 & + \\
\hline & & & & & & +4 & + & + & - & + & + & + & - & -1 & $-1-$ & 5 & - & - & $-1-$ & - & - & -1 & - & - & 1 & -1 & - & 4 & -1 & -1 & - & - & $-1+$ & +1 & - & $-1=$ & & + \\
\hline & & & & & & & & & - & & & + & - & - & $-1-$ & 7 & - & - & $-1-$ & & - & -1 & - & + & 2 & -2 & & 6 & -1 & - & - & - & -1 & $-1+$ & - & $7-$ & - & - \\
\hline & & & & & 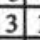 & 1 & 1 & -1 & - & - & + & & - & - & $-1-$ & 4 & -1 & - & $-1-$ & & - & - & - & - & 2 & - & & 4 & -1 & - & - & - & - & $-1-$ & - & $E$ & - & - \\
\hline & & & - & -1 & 2 & -1 & 2 & ++ & - & - & + & + & -1 & -1 & $-7+$ & 6 & - & - & $-1-$ & $1-$ & - & -2 & - & + & + & ++ & & 6 & - & -1 & - & - & - & $-1+$ & - & $7=$ & - & - \\
\hline & & & - & -1 & ++ & +2 & 2 & $-1+$ & - & - & + & 1 & - & $-1-$ & $-1-$ & 6 & + & - & $-1-$ & $1-$ & - & -2 & + & - & \begin{tabular}{|l|l|}
2 & \\
\end{tabular} & $1+$ & - & 10 & - & - & + & - & - & + & - & -2 & $1-$ & - \\
\hline & & & & & $1+$ & +3 & 3 & -1 & - & - & + & + & - & - & -1 & 3 & - & - & - & - & - & -1 & $1-$ & - & 1 & $-1+$ & & 5 & + & - & - & - & -1 & -3 & - & $7-$ & - & - \\
\hline & & & + & & & +3 & & 11 & - & - & & & - & - & -2 & + & + & - & $-1-$ & & - & -3 & 3 & - & - & -1 & - & 20 & -1 & & 2 & - & + & -2 & 2 & - & - & - \\
\hline & & & + & & 4 & -6 & 6 & $-1+$ & +7 & -1 & & & + & -1 & +1 & 6 & -1 & -1 & $-1-$ & & -1 & -+ & + & - & -1 & ++ & -1 & 12 & -1 & +1 & 1 & -1 & ++ & +2 & + & -1 & $1-$ & - \\
\hline & & & - & -1 & 2 & -4 & 4 & $-1+$ & +7 & - & + & & - & - & $-1+$ & 5 & + & - & $-1-$ & - & - & -- & - & - & -1 & ++ & & 9 & $-1+$ & +- & + & - & + & -2 & 4 & $-1-$ & $1-$ & - \\
\hline & & & -1 & -1 & + & -1 & -1 & -1 & $1-$ & - & + & + & - & -1 & -1 & 4 & - & - & $-1-$ & Z & - & -1 & $1-$ & - & 4 & -+ & & 7 & -1 & - & - & - & -1 & -2 & - & \pm & - & - \\
\hline & & & \begin{tabular}{|l|l}
1 \\
\end{tabular} & -1 & & -1 & - & -1 & 17 & + & + & -1 & + & +1 & -1 & 1 & + & -1 & $-1-$ & E & - & -1 & $1-$ & & 4 & $-1+$ & & \begin{tabular}{|l|}
4 \\
\end{tabular} & -1 & & + & -1 & +1 & -6 & -1 & 2 & & + \\
\hline & & & \begin{tabular}{|l|}
1 \\
\end{tabular} & - & & - & & & -1 & & & & -1 & - & +1 & 2 & + & -1 & $-1-$ & & - & -3 & $3-$ & - & + & ++ & & 13 & -+ & & 1 & - & + & -6 & - & 1 & - & - \\
\hline & & & - & -1 & 1 & -2 & $2+$ & +1 & $1-$ & - & - & & - & - & -1 & 1 & + & + & +- & E & - & +1 & $1-$ & & \begin{tabular}{|l|l|}
3 \\
\end{tabular} & $-1-$ & & 15 & - & - & - & -1 & + & 3 & \begin{tabular}{|l|}
1 \\
\end{tabular} & 2 & - & - \\
\hline & & & - & -1 & & - & & & $=-$ & - & - & - & - & -1 & $=1$ & 3 & - & -1 & $\Rightarrow-$ & & - & -1 & $1+$ & - & + & - & - & 3 & $-1=$ & - & - & -1 & - & -6 & - & \pm & - & - \\
\hline & & & -1 & -1 & 1 & 1 & -1 & $\pi$ & $1-$ & - & -1 & -1 & -1 & -1 & $-1+$ & 2 & - & -1 & $-1-$ & - & 1 & +1 & $1-$ & - & 2 & $7+$ & & 4 & -1 & $-1-$ & + & -1 & $-1-$ & -3 & - & 2 & - & - \\
\hline & & & & & & + & & $y-1=$ & $=$ & - & - & - & - & -1 & -2 & - & - & -1 & $-1-$ & E & - & \begin{tabular}{|l|l}
2 \\
\end{tabular} & $2-$ & $\exists$ & 3 & $-1+$ & & 7 & -1 & 7 & - & -1 & $-1-$ & -4 & -1 & \pm & $1-$ & 2 \\
\hline & & & - & -1 & $2+$ & +4 & + & 5 & $5-$ & & & & - & - & $-7+$ & 1 & - & -1 & $-1-$ & & -1 & -2 & & - & 3 & $-1+$ & & 21 & - & & - & -1 & 2 & -12 & - & + & - & + \\
\hline & & & + & -1 & 1 & +3 & 3 & 72 & $2-$ & - & \begin{tabular}{|l|}
1 \\
\end{tabular} & - & - & -- & - & 9 & + & -1 & $-1-$ & & - & -+ & - & $E$ & 2 & $-1+$ & & 11 & -1 & & 2 & -1 & 1 & -2 & - & 1 & - & - \\
\hline & & & + & -1 & 2 & +3 & & -2 & $2-$ & + & & -1 & -1 & $1-$ & -1 & 3 & - & -1 & $-1-$ & $\overline{-}$ & -1 & $-1+$ & 2 & - & 2 & $1+$ & - & 14 & $-1+$ & +- & - & -1 & - & -3 & - & - & - & - \\
\hline & & & -1 & -1 & -1 & $-1+$ & + & 2 & $21-$ & - & - & -1 & -1 & -1 & $-1-$ & + & - & -1 & -1 & - & -1 & $-1+$ & $1-$ & - & -1 & \begin{tabular}{l|l}
11 \\
\end{tabular} & - & 13 & $-1-$ & $-1-$ & $t$ & - & -1 & -3 & - & -1 & 1 & - \\
\hline & & & -1 & -1 & + & ++ & + & 1 & $1-$ & - & + & + & + & - & - & 1 & - & - & $-1-$ & 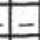 & - & -+ & 1 & - & - & + & & 8 & -+ & + & + & -1 & $1-$ & -2 & -1 & - & $\exists$ & - \\
\hline & & & -1 & -1 & & ++ & & 1 & & & & - & - & -1 & & 1 & - & - & & & -1 & -1 & - & & \begin{tabular}{|l|l|}
6 \\
\end{tabular} & $1-$ & + & 5 & -1 & $\exists$ & 1 & - & + & -4 & & 1 & - & \\
\hline & & & -1 & -1 & + & & + & 71 & $1-$ & & + & -1 & - & -1 & -1 & + & - & - & $-1-$ & & -1 & $-1+$ & $1-$ & $=$ & -1 & $1-$ & + & \begin{tabular}{|l|}
4 \\
\end{tabular} & -1 & $=$ & - & -1 & $12=$ & 3 & + & \pm & 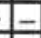 & - \\
\hline & & & + & - & & -1 & 7 & -1 & -1 & + & & -1 & - & -1 & - & 2 & -1 & -1 & $-1-$ & & -1 & + & + & - & - & $=+$ & + & 7 & -1 & -1 & - & -1 & 6 & 5 & - & 1 & - & - \\
\hline & & & -1 & $f$ & + & -1 & - & & $1-$ & - & & -1 & -1 & -1 & ++ & 2 & -1 & -1 & $-1-$ & & -1 & +1 & & & 2 & ++ & -1 & 7 & -1 & $\pi$ & + & $E$ & 1 & -3 & & 8 & $1-$ & - \\
\hline & & & -1 & -1 & 1 & $=$ & - & & 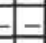 & -1 & & - & - & - & $7+$ & - & - & - & - & & -1 & $+1-$ & $\Rightarrow$ & & 4 & $=1+$ & & 12 & -1 & & & & 3 & 6 & - & 3 & $=$ & \\
\hline & & & + & -1 & & & & & & & & & & & & 4 & + & & & & - & $1-$ & & & 4 & & & 3 & & & & & $7-$ & -4 & & 4 & - & \\
\hline & & & -1 & -1 & + & & -7 & 2 & $2-$ & -1 & & + & -1 & - & $-1+$ & - & - & -1 & $-1-$ & & - & $-1-$ & 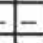 & & 2 & $7-$ & & 3 & $-1-$ & $\exists$ & + & & \begin{tabular}{l|l}
6 & - \\
\end{tabular} & + & - & 7 & $\exists$ & - \\
\hline & & & + & -1 & + & -1 & -1 & $-1-$ & $1-$ & -1 & -1 & -1 & -1 & $-1-$ & -1 & - & - & $-1-$ & $-1-$ & & -1 & ++ & 7 & $E$ & + & $-1-$ & + & 3 & -1 & 7 & + & -1 & 4 & 3 & -1 & 5 & - & - \\
\hline & & & & & & & + & -1 & & + & & & & & & 2 & - & & & & - & +3 & & & + & $-1+$ & & & -1 & -1 & + & & -1 & 8 & & + & & \\
\hline \multicolumn{39}{|l|}{, $90-9 Z^{4}$} \\
\hline & & & & & & & & & & & & & & & & & & & & & & & & & & & & & & & & & & & & & & \\
\hline $7-6,38-40$ & 002,000 & & & & & & & & & & & & & & & & & & & & & & & & & & & & & & & & & +6 & & & & \\
\hline
\end{tabular}

${ }^{\mathrm{a}}$ Only very rare debris of diatoms present.

$+=$ Trace

$-=$ Absent 
TABLE 1 - Continued

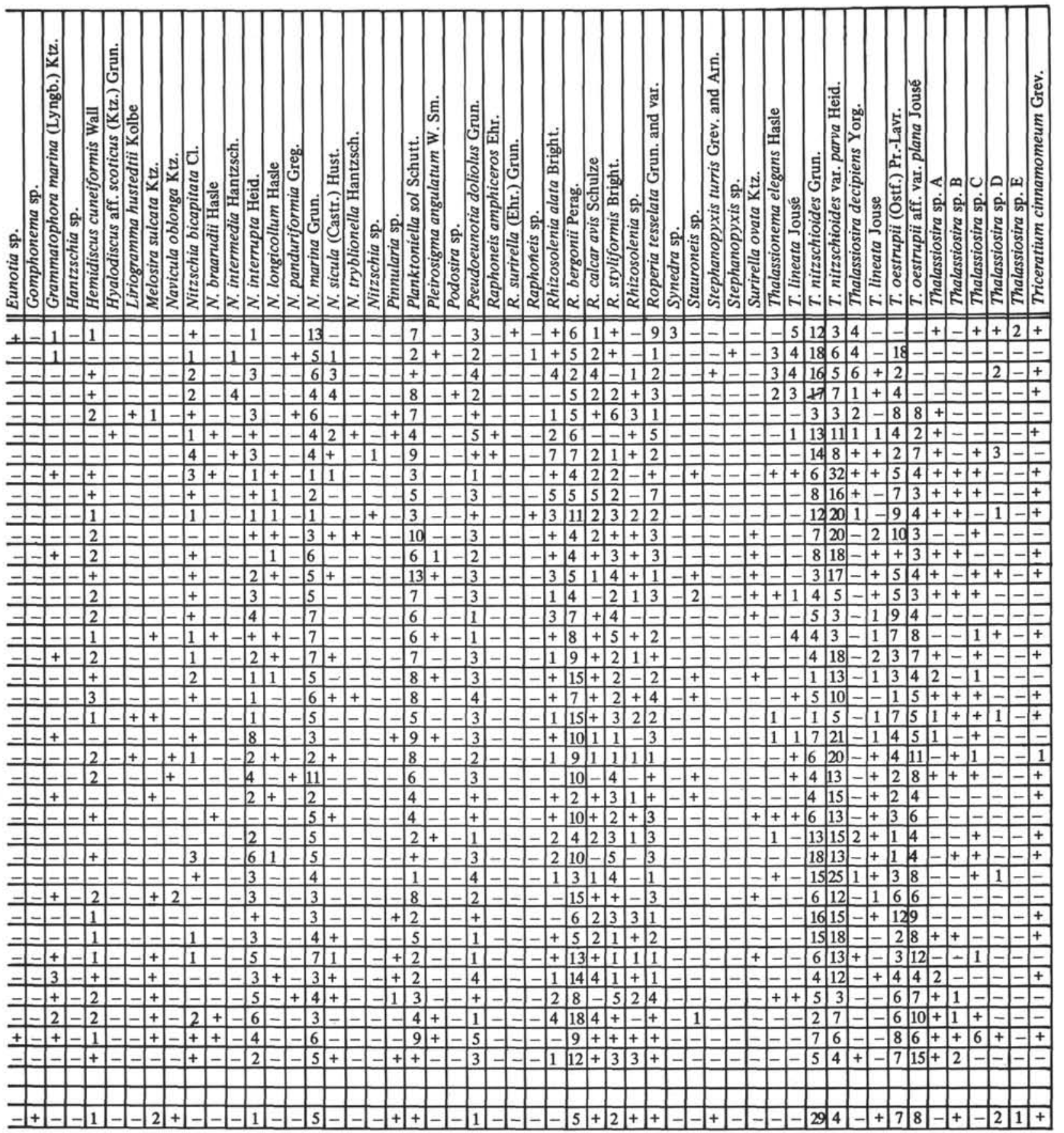




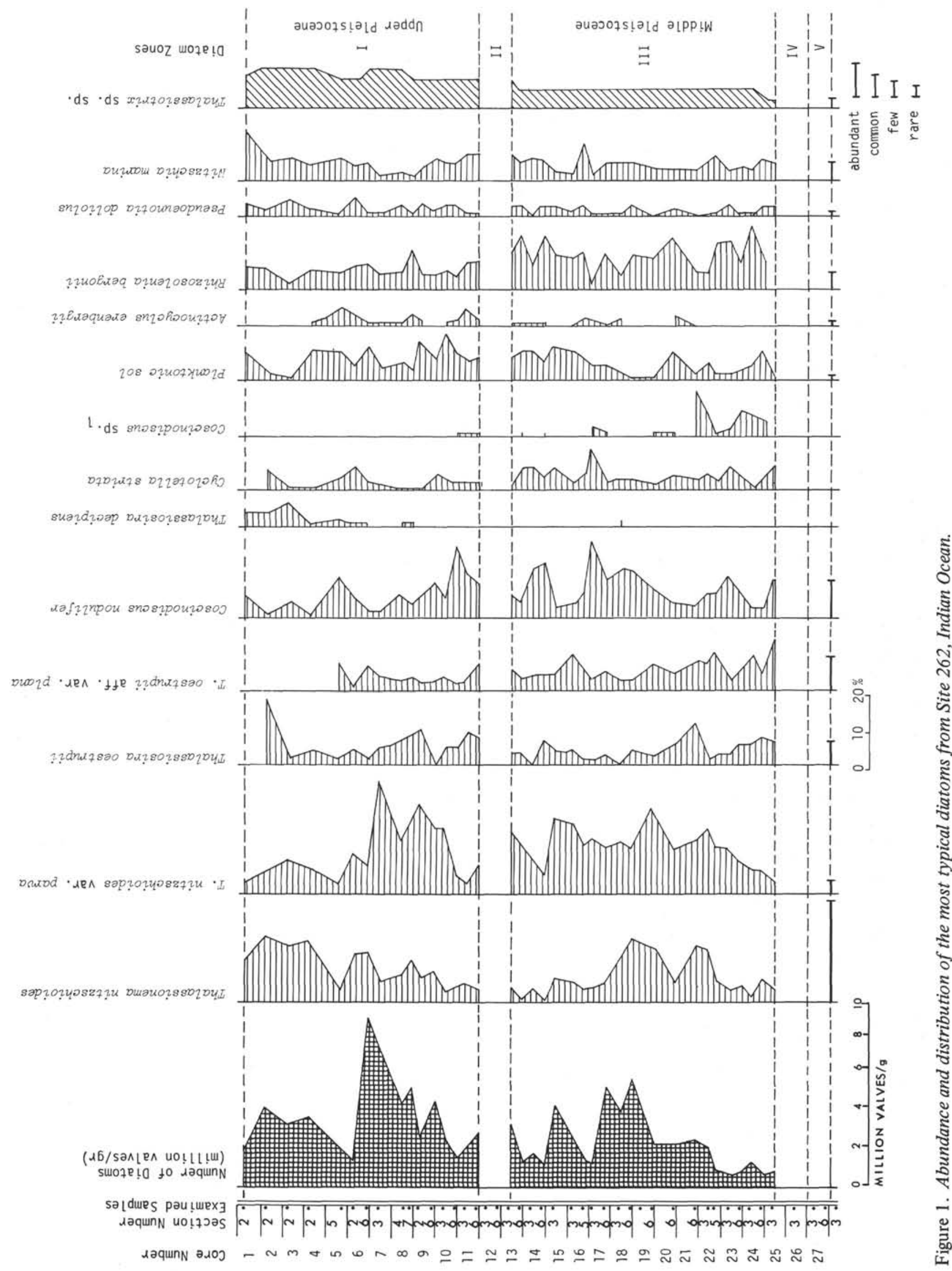


Zone III - Cores 13-25

\} Middle Pleistocene

Zone IV - Core 26, Sections 3, 6

Zone V - Core 27, Section 6

?Middle Pleistocene

\section{CHARACTERISTICS OF DIATOM COMPLEXES BY ZONES (FROM TOP DOWN)}

Zone I is characterized by an abundance of diatoms, with the number of valves/g of sediment reaching a maximum value of $9,099,200$ in Core 6, Section 6 . Debris of Thalassionema, Thalassiotrix, etc., is also abundant but was not included in the total. Zone $I$ is similar to the lower zones in specific composition and relative percentages of diatoms; however, some species attain their highest level in Zone I, such as Thalassionema nitzschioides var. parva (32\%), Thalassiosira oestrupii (18\%), Planktoniella sol (13\%), and Pseudoeunotia doliolus (5\%).

Some peculiarities are noted in the distributions of certain species: Thalassiosira decipiens, a moderate- to cold-water type, occurs mainly in the upper part of Zone I where it accounts for $6 \%$ of the total. It occurs only sporadically in Zones III and V. Cyclotella striata, a cold-water species, typical for the sublittoral zone of oceans, is represented by single specimens in Zone I but is more abundant in the other zones.

Judging from the diatom assemblage, the sediments of Zone I were formed in the pelagic zone of the ocean. This is indicated by the prevalence of typical oceanic species. The relatively high concentration of diatoms in sediments of Cores 1-11 indicates a decrease in dilution compared with sediments of Cores 12-25. The diatoms in the upper cores from Site 262 correspond to the Recent tropical flora of the Indian Ocean (Kozlova, 1968;1969; Kazarina and Demidenko, 1974).

Zone II, which includes Core 12, Sections $3-6$, is characterized by a nearly complete absence of diatoms.

Zone III-Cores 13-25-contains rather numerous, but less abundant diatoms than Zone I. The maximum abundance is in Core 18, Section 6. The diatoms gradually decrease downward reaching a minimum of 720,000 valves/g of sediment in Core 23 , Section 3. A similar decrease occurs in the number of specimens for certain oceanic species such as Ethmodiscus rex, Thalassiotrix sp., Thalassionema sp., and Chaetoceros sp. Such species are abundant to common in Zone I but are sparse in the upper part of Zone III, and rare in the lower part of Zone III. Hence, these species form an insignificant part of the diatom flora of Zone III.

With few exceptions, species typical for Zone I also occur in Zone III. The chief exceptions are Thalassiosira decipiens, which is present only in Zone I, and Coscinodiscus sp. (Plate 2, Figures 10, 11; Plate 4, Figures 4,5 ), which is present mainly in sediments of Zone III. This latter species is new and its ecological and biostratigraphic characteristics are not well defined. In the tropical area of the Indian Ocean this species is present both in Pleistocene and Pliocene deposits (Kazarina and Demidenko, 1974) and has also been reported in surface layers of Recent sediments (Kozlova, 1969).

Some diatom species of Zone III show peculiar morphological features which distinguish them from typical modern forms and indicate their older age. Thus, for instance, dimensions of valves of Coscinodiscus nodulifer decrease with extension and duplication of the "nodule"; among Thalassiosira oestrupii, both small and normal-size forms occur together. The small forms are similar to Thalassiosira oestrupii var. plana Jouse (1968a) described from Pacific Ocean sediments of middle Pleistocene age. Rhizosolenia bergonii forms are larger than normal and resemble forms transitional to Rhizosolenia praebergonii Muchina. It is presently assumed that extinction of Rhizosolenia praebergonii marks the Pliocene-Pleistocene boundary in sediments of the tropical Pacific Ocean (Jousé and Muchina, 1973; Burckle, 1972).

In addition, the number of sublittoral species increases in sediments of Zone III. Similar variations in the diatom flora of the Indian Ocean were pointed out earlier by Greville and Kolbe for the region of the Seychelle Islands where, in sediments recovered from considerable depth and at great distance from land, a large number of sublittoral and benthic species was present (Kolbe, 1957). We observe mainly the increase of the species Cyclotella striata typical for deltaic environments in moderate latitudes. In ChileanPeruvian offshore sediments Cyclotella striata is typical for the region of cold currents (Jousé, 1972).

In Zone III the number of sponge spicules increases as the ocean diatom species, mainly Ethmodiscus rex, Thalassiotrix sp., Thalassionema sp., and Chaetoceros sp. decrease. The increase in sponge spicules and sublittoral diatoms and the decrease in oceanic diatoms indicate that the sediments of Zone III (Cores 13-25) were deposited under shallower water conditions than the sediments of Zone I.

Diatom floras with species morphologically different from modern forms correspond to a Pleistocene evolutionary stage of diatom development.

In Zone IV, there are insufficient specimens to characterize a diatom flora.

In Zone V, small numbers of diatoms occur in Core 27. Section 6; in Section 3 of Core 27 only single specimens are present. The diatom flora in Core 27 is similar to that of Zone III.

No diatoms were observed in the interval between Core 28 and the bottom of the hole at Core 47.

\section{BIOSTRATIGRAPHIC AND PALEOGEOGRAPHIC CONCLUSIONS}

Sediments of Cores 1-27 contain diatom floras typical of the Pleistocene of the Indian Ocean. Associations of diatoms are similar to those known for the Pleistocene of the equatorial-tropical area of the Indian Ocean (cores 4599, 5003, and 5174 of the Institute of Oceanology of the Academy of Sciences of the USSR) (Kozlova, 1970; Kazarina and Demidenko, 1974).

The Mesocena elliptica (Ehr.) Defl. Zone corresponding in equatorial-tropical areas of the Pacific and Indian Oceans to deposits of lower, and probably the lower part of middle, Pleistocene could not be established in the sediments of Site 262. Morphologically the diatoms of Zones III and IV compare closely with middle Pleistocene floras of subtropical and tropical areas of the Pacific Ocean (Jousé, 1968b). 


\section{A. P. JOUSÉ, G. H. KAZARINA}

The sediments of Zone I, which contain modern diatoms, correspond to the upper Pleistocene and Holocene. Consequently, the nearly 250 meters of diatom-bearing sediments were formed during the middle and upper Pleistocene and Holocene, i.e., in the last 0.7 to 1.0 m.y. Thus, sedimentation took place at a very high rate during this time.

Ecological differences in the diatom floras of Zones I and III indicate that paleogeographic conditions varied during deposition of these sediments (Sections 1-27). Oceanic diatoms are dominant in Zone I indicating that the sediments were deposited in the pelagic zone of the ocean. The relatively high concentration of diatoms here points to less dilution in this zone compared with Zone III. Cyclotella striata, a sublittoral, moderate- to coldwater species, indicates that the sediments of Zone III were formed under shallower and colder water conditions than those of Zone I.

From Core 28 upwards there is an increase in the content of typical oceanic forms such as Ethmodiscus rex, Thalassiotrix, Thalassionema, and Chaetoceros. Thus, variations in diatom floras in this interval, which represents a considerable part of the Pleistocene, proceeded in strict succession and with definite consistency.

\section{REFERENCES}

Burckle, L. H., 1972. Late Cenozoic planktonic diatom zones from the eastern equatorial Pacific. In First Symposium on
Recent and Fossil Marine Diatoms: Nova Hedwigia, v. 39, p. 217-246.

Jouse, A. P., 1968a. New species of diatoms in bottom sediments of the Pacific and the Okhotsk Sea: Nov. Systemat. Plant. Vasculal. Moscow, (Nauka), 12-21, (in Russian). 1968b. Stratigraphy of Pleistocene sediments in the Pacific Ocean: Comm. Study Quatern. Per. Bull. v. 35, p. 119. Moscow (Nauka), (in Russian).

1972. Diatoms in the surface sediment layer of the Chilean-Peruvian Region of the Pacific Ocean: Oceanology, v. 12, p. 831-841, (in Russian).

Jouse, A. P. and Muchina, V. V., 1973. Zone Mezocena elliptica (Ehr.) Defl. in the Pleistocene sediments of the Pacific Ocean: Oceanology, v. 13, p. 467-475, (in Russian).

Kazarina, G. H. and Demidenko, E. L., 1974. Diatom and paleomagnetic zones in the sediments of core 4599 (Indian Ocean). In Micropaleontology of oceans and meeres: Moscow (Nauka), p. 83-93, (in Russian).

Kolbe, R. W., 1957. Diatoms from equatorial Indian Cores. Swedish Deep-Sea Exped. Rept., p. 1-50.

Kozlova, O. G., 1968. Diatoms and silicoflagellatae of the Indian Ocean. In Fossil diatoms of the USSR: Moscow, (Nauka), p. 119-127, (in Russian).

1969. Quantitative distribution and species composition of diatoms and silicoflagellate in the surface layer of sediments of the Indian Ocean. In Micropaleontology and organogenous sedimentation in the oceans: Moscow (Nauka), p. 28-51, (in Russian).

1970. Biostratigraphy of sediments of the equatorial zone of the Indian Ocean: Oceanology, N 3, v. 10, p. 479487, (in Russian). 


\section{PLATE 1}

Figure 1 Actinocyclus ellipticus $\mathrm{f}$. lanceolata $\mathrm{Grun}$ Sample 10-6, 65-67 cm, $51 \mu$ in length.

Figure 2, 3 Actinocyclus erenbergii var. tenella Hust 2. Sample $14-6,70-72 \mathrm{~cm}, 35 \mu$ in diameter. 3. Sample 10-6, 65-67 cm, $28 \mu$ in diameter.

Figure 4, 5 Actinoptychus bipunctatus Lohm 4. Sample $10-3,58-60 \mathrm{~cm}, 28 \mu$ in diameter. 5. Sample $10-6,65-67 \mathrm{~cm}, 22 \mu$ in diameter.

Figure 6 Actinoptychus undulatus Ralfs Sample 9-6, 20-22 cm, $40 \mu$ in diameter.

Figure 7 Asteromphalus arachne $\mathrm{Ralfs}$ Sample 11-3, 16-18 cm, $45 \mu$ in diameter.

Figure $8 \quad$ Asteromphalus sp.

Sample 10-6, 65-67 cm, $38 \mu$ in diameter.

Figure 9 Bacteriastrum hialinum Lauder Sample 9-6, 20-22 cm, $13 \mu$ in diameter.

Figure $10 \quad$ Cyclotella striata (Ktz.) Grun Sample 9-6, 20-22 cm, $38 \mu$ in diameter.

Figure 11 Cocconeis pseudomarginata Gregory Sample 10-6, 65-67 cm, $62 \mu$ in length.

Figure 12 Cocconeis sp.

Sample 18-6, 15-17 cm, $38 \mu$ in length.

Figure 13 Planktoniella sol Schutt

Sample 9-6, 20-22 cm, $52 \mu$ in diameter. 
PLEISTOCENE DIATOMS, SITE 262

PLATE 1
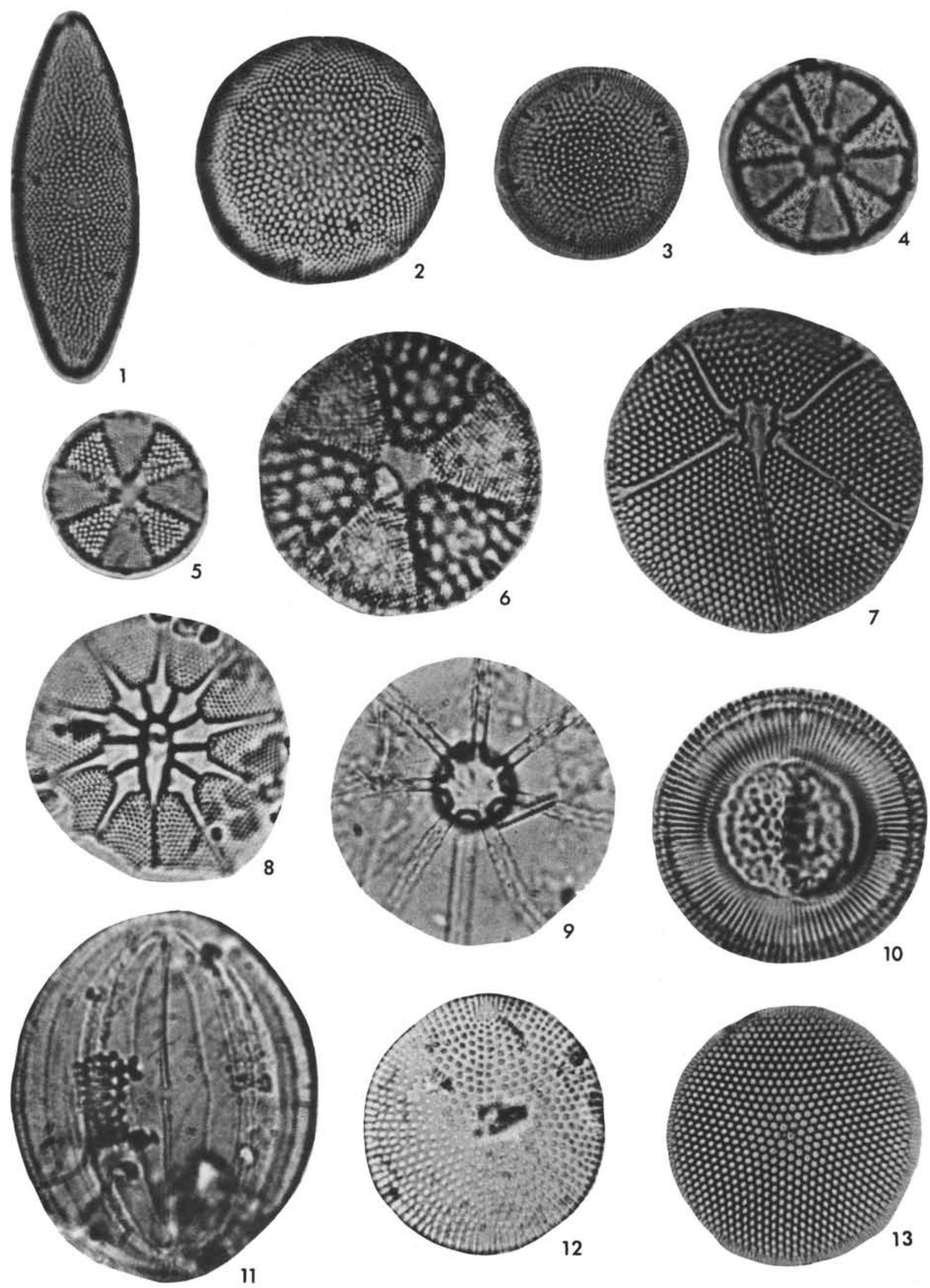


\section{PLATE 2}

Figure I Coscinodiscus africanus Yanisch Sample 9-6, 20-22 cm, 30 $\mu$ in diameter.

Figure 2 Coscinodiscus crenulatus Grun Sample $18-6,15-17 \mathrm{~cm}, 34 \mu$ in diameter.

Figure 3 Coscinodiscus domifactus Hendey Sample 14-3, 95-96 cm, $38 \mu$ in diameter.

Figure 4 Coscinodiscus nodulifer A. Schmidt Sample 10-6, 65-67 cm, 50 $\mu$ in diameter.

Figure 5 Coscinodiscus nodulifer $\mathrm{A}$. Schmidt Sample 18-6, 15-17 cm, $38 \mu$ in diameter.

Figure 6 Coscinodiscus nitidus $\mathrm{Greg}$

Sample 20-6, 18-20 cm, $39 \mu$ in diameter.

Figure 7-9 Coscinodiscus sp. A.

7. Sample $11-6,28-30 \mathrm{~cm}, 23 \mu$ in diameter.

8. Sample $20-6,18-20 \mathrm{~cm}, 20 \mu$ in diameter.

9. Sample $27-6,14-16 \mathrm{~cm}, 25 \mu$ in diameter.

Figure $10 \quad$ Diploneis bombus $\mathrm{Ehr}$

Sample 9-6, 20-22 cm, $35 \mu$ in length.

Figure 11 Diploneis suspecta A. Schmidt Sample 14-6, 70-72 cm, $41 \mu$ in length.

Figure 12 Diploneis sp.

Sample 14-3, 95-97 cm, $26 \mu$ in length.

Figure 13 Glyphodesmis nancoorense Grun Sample 14-6, 70-72 cm, $65 \mu$ in length.

Figure 14, 15 Hemidiscus cuneiformis Wall

14. Sample 9-6, 20-22 cm, 30 $\mu$ in length.

15. Sample $10-3,58-60 \mathrm{~cm}, 50 \mu$ in length.

Figure $16 \quad$ Nitzschia interrupta Heid Sample 8-4, 105-107 cm, $42 \mu$ in length.

Figure $17 \quad$ Nitzschia panduriformis Greg Sample 11-3, 16-18 cm, $48 \mu$ in length.

Figure 18 Nitzschia marina Grun Sample 10-6, 65-67 cm, $130 \mu$ in length.

Figure $19 \quad$ Pseudoeunotia doliolus Grun

Sample 10-6, 65-67 cm, $65 \mu$ in length. 
PLATE 2
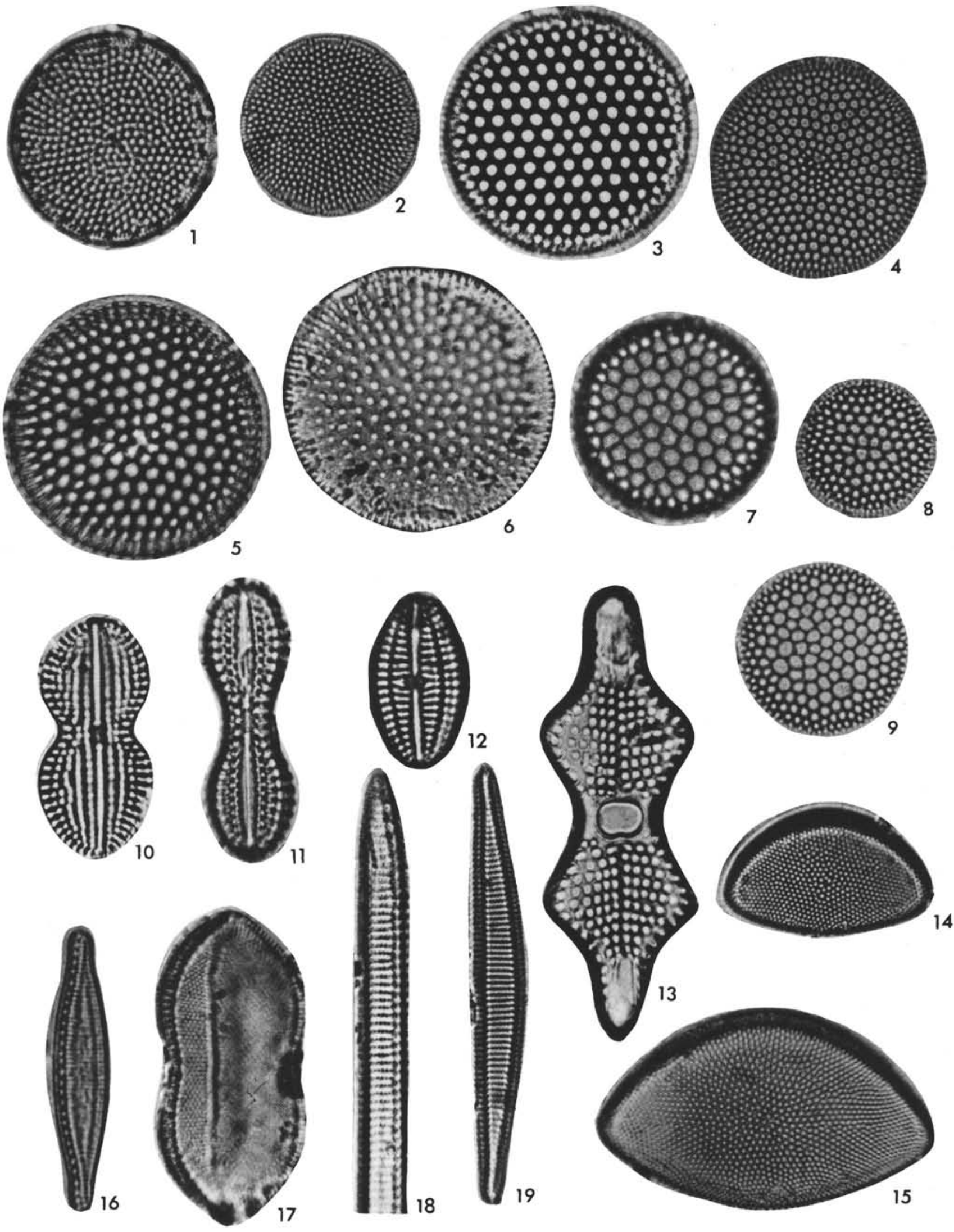


\section{PLATE 3}

Figure $1 \quad$ Rhizosolenia alata Bright Sample 14-3, $95-97 \mathrm{~cm}, 45 \mu$ in length.

Figure 2, 3 Rhizosolenia bergonii Perag

2. Sample $10-6,65-67 \mathrm{~cm}, 48 \mu$ in length.

3. Sample $11-3,16-18 \mathrm{~cm}, 65 \mu$ in length.

Figure 4, $5 \quad$ Rhizosolenia styliformis Bright

4. Sample 11-3, 16-18 cm, 63 $\mu$ in length.

5. Sample $10-6,65-67 \mathrm{~cm}, 48 \mu$ in length.

Figure 6,7 Rhizosolenia sp.

6. Sample 3-2, $38-40 \mathrm{~cm}, 35 \mu$ in length.

7. Sample $7-3,130-132 \mathrm{~cm}, 75 \mu$ in length.

Figure 8

Roperia tesselata Grun

Sample 4-2, 16-18 cm, $28 \mu$ in diameter.

Figure 9, 10 Thalassionema nitzschioides Grun

9. Sample 18-6, 15-17 cm, $110 \mu$ in length.

10. Sample $18-6,15-17 \mathrm{~cm}, 32 \mu$ in length.

Figure 11-15 Thalassiosira oestrupii (Ostf.) Pr.-Lavr

11. Sample 9-6, 20-22 cm, $25 \mu$ in diameter.

12. Sample $10-6,65-67 \mathrm{~cm}, 20 \mu$ in diameter.

13. Sample $10-6,65-67 \mathrm{~cm}, 18 \mu$ in diameter.

14. Sample $18-3,13-15 \mathrm{~cm}, 15 \mu$ in diameter.

15. Sample $18-6,15-17 \mathrm{~cm}, 12 \mu$ in diameter.

Figure 16 Thalassiosira sp. A

Sample 4-2, 16-18 cm, $28 \mu$ in diameter.

Figure 17 Thalassiosira sp. C

Sample 4-2, 16-18 cm, $48 \mu$ in diameter.

Figure 18, 19 Thalassiosira sp. B

18. Sample 9-6, 20-22 cm, $22 \mu$ in diameter.

19. Sample $9-6,20-22 \mathrm{~cm}, 27 \mu$ in diameter. 
PLATE 3

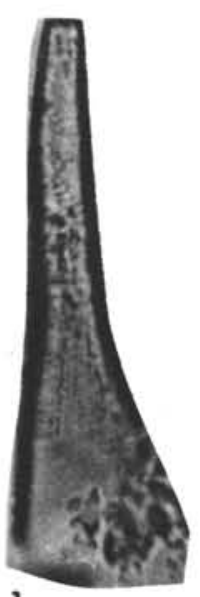

1.
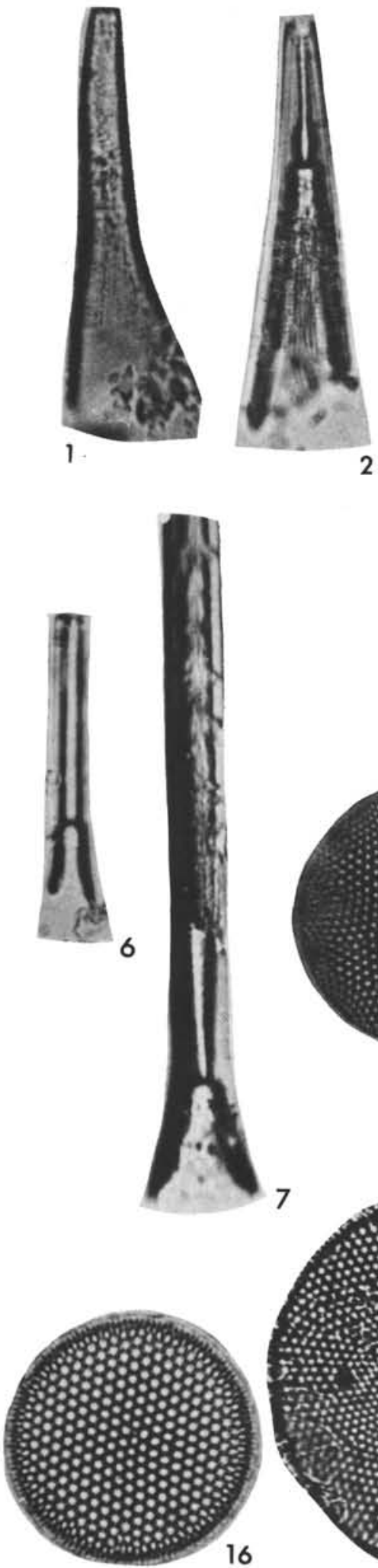
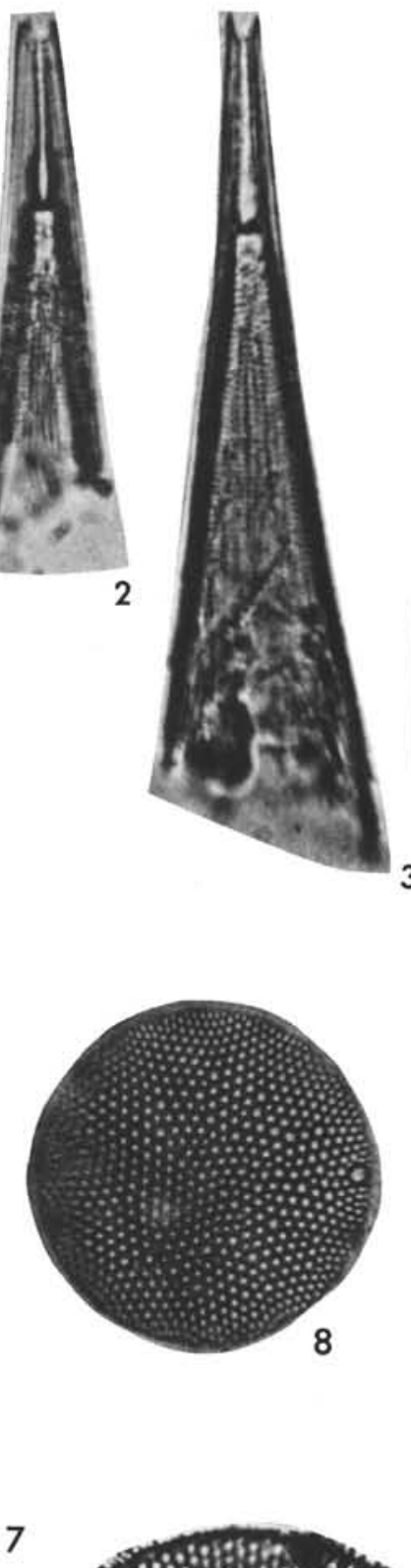
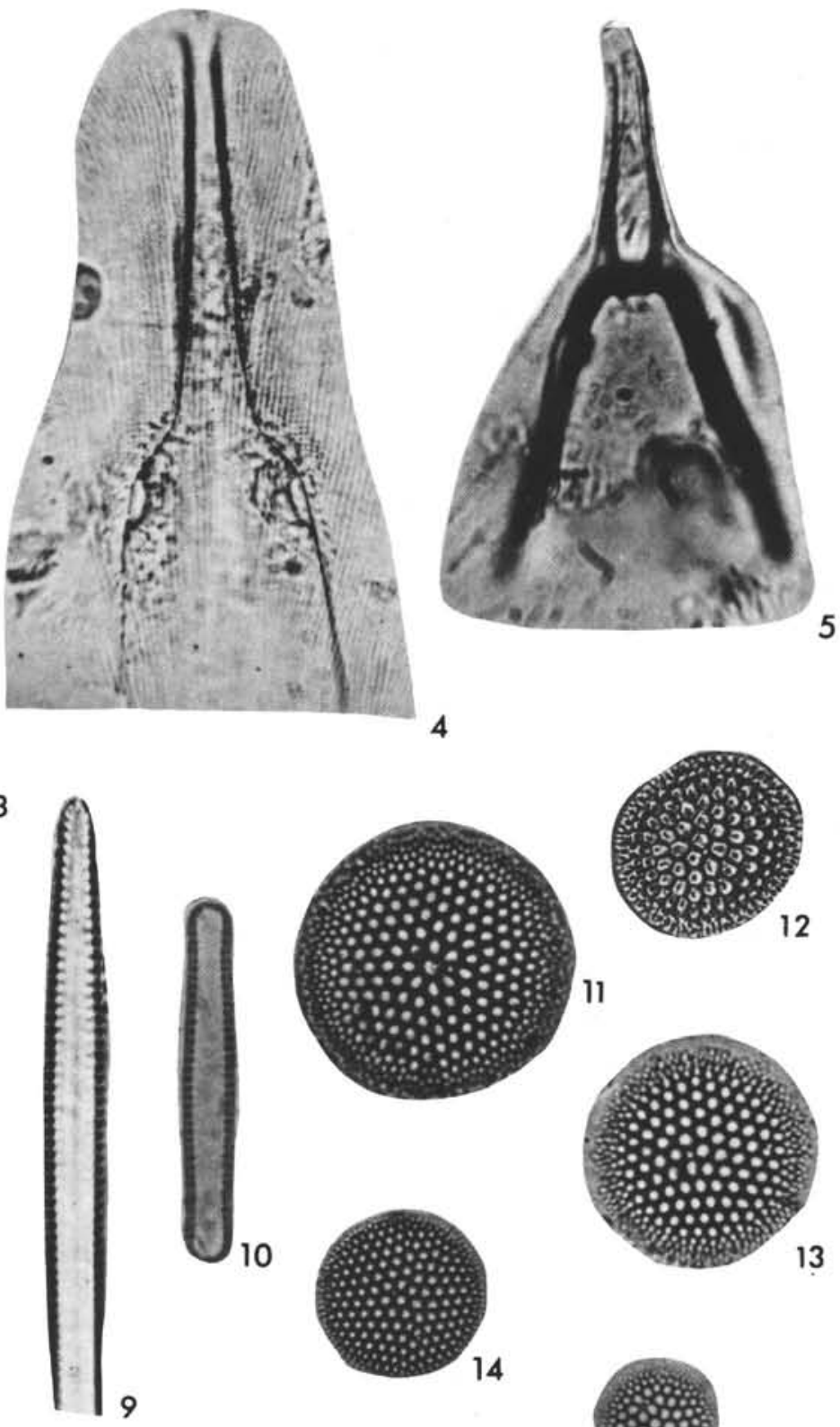

\section{1}
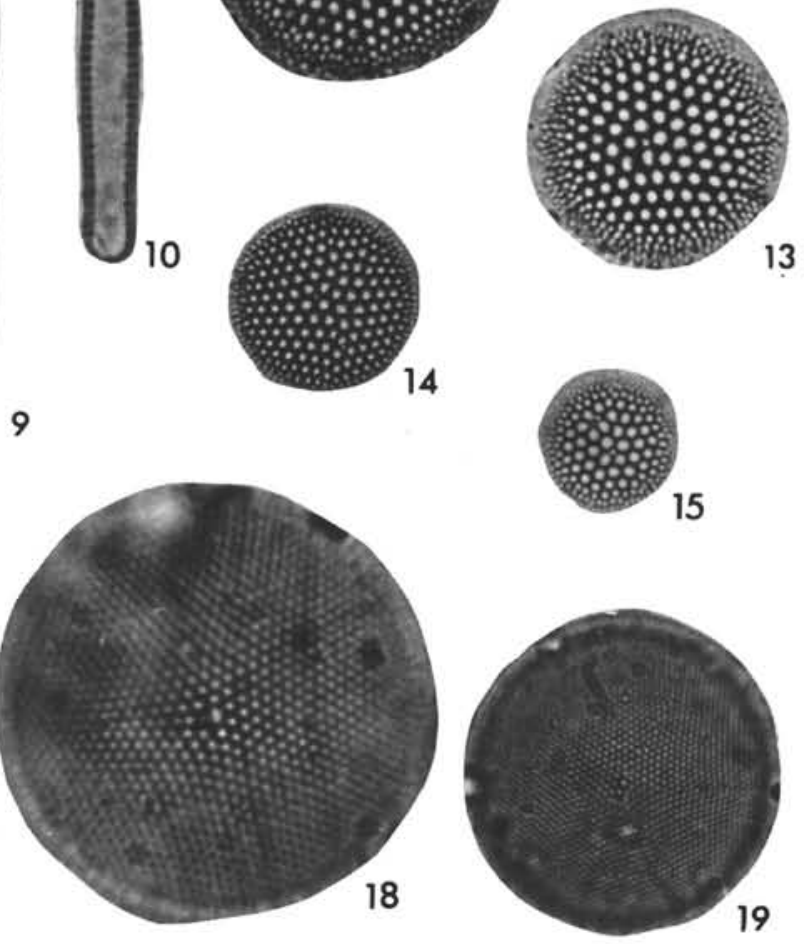


\section{PLATE 4}

Figures 1, 2, 5-12, Sample 8-4, 105-107 cm; Figures 3, 4, Sample 14-3, 95-97 cm.

Figure 1 Actinocyclus ellipticus $\mathrm{f}$. lanceolata Grun $\times 2200$.

Figure $2 \quad$ Asteromphalus arachne $\mathrm{Ralfs} \times 3850$.

Figure $3 \quad$ Asteromphalus aff. robustus Castr $\times 1750$.

Figure $4 \quad$ Asterolampra marylandica Ehr $\times 2200$.

Figure $5 \quad$ Bacteriastrum hialinum Lauder $\times 2700$.

Figure 6 Coscinodiscus africanus (w.s.m.) Yanisch $\times 2500$.

Figure 7,8 Coscinodiscus crenulatus var. nodulifer Lohm 7. $\times 3000$.

8. $\times 3000$

Figure $9 \quad$ Coscinodiscus lineatus $\mathrm{Ehr} \times 1050$.

Figure 10-12 Coscinodiscus nodulifer A. Schmidt

10. $\times 1000$.

11. $\times 3000$.

12. $\times 3000$. 
PLATE 4
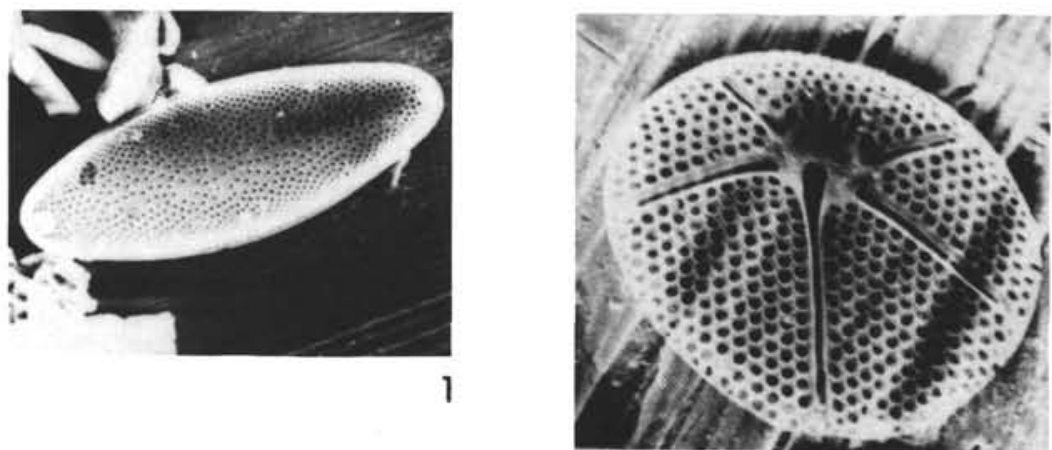

2

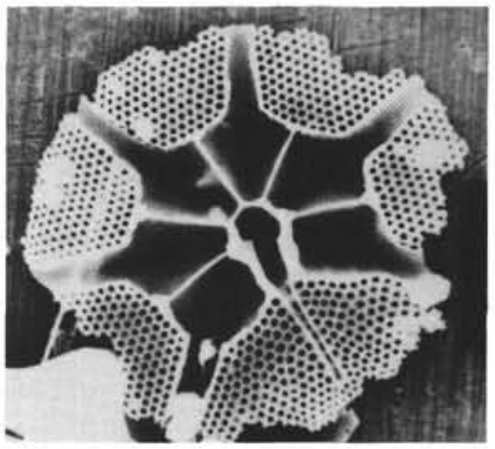

3

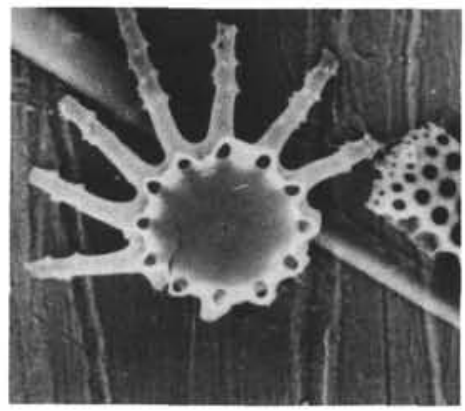

5

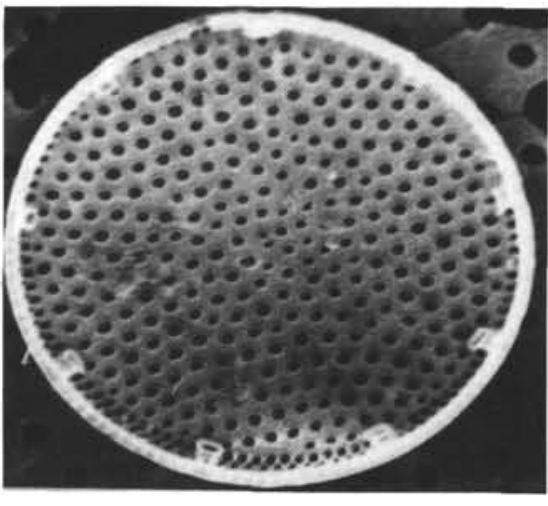

7
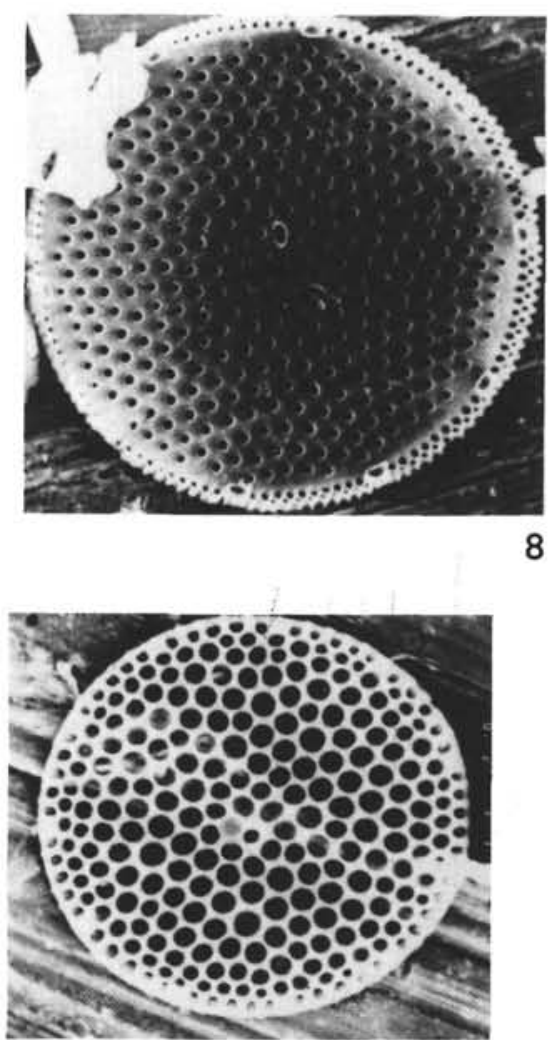

11

8

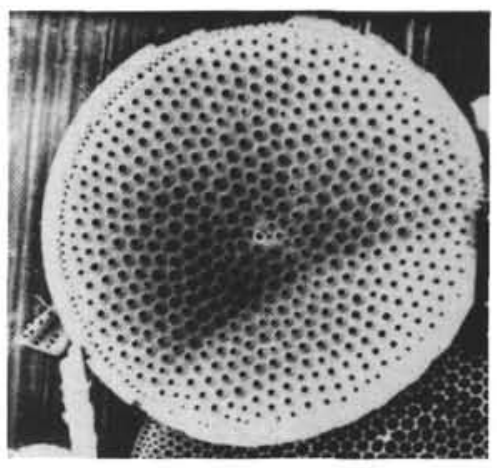

6
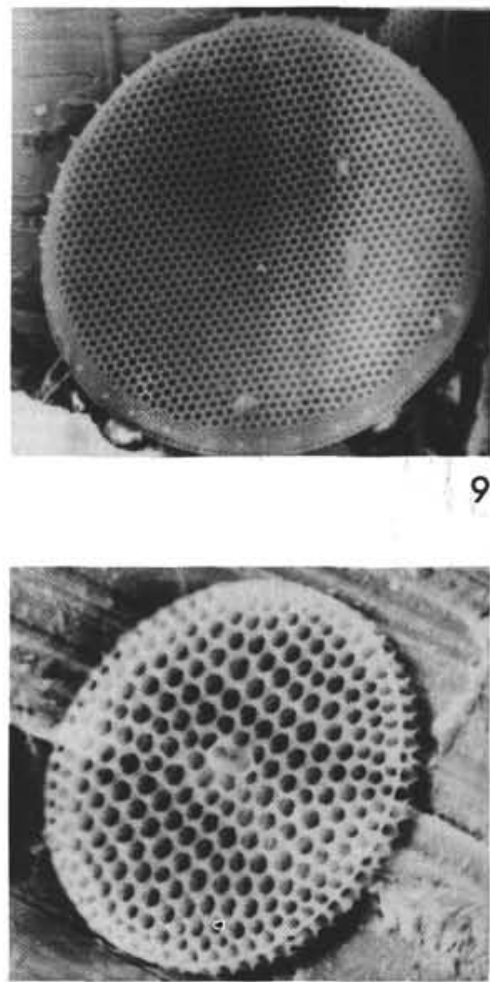


\section{PLATE 5}

Figures 1-5, Sample 14-3, 95-97 cm; Figures 6-12, Sample 8-4, 105-107 cm.

Figure 1, 2 Coscinodiscus aff. nodulifer A. Schmidt 1. $\times 200$.

2. $\times 1050$.

Figure 3 Coscinodiscus radiatus $\mathrm{Ehr} \times 1000$.

Figure 4, $5 \quad$ Coscinodiscus sp. A

4. $\times 4000$.

5. $\times 3000$.

Figure 6-8 Hemidiscus cuneiformis Wall

6. $\times 1550$.

7. $\times 2200$.

8. $\times 1700$.

Figure $9 \quad$ Navicula oblonga $\mathrm{Ktz} \times 1000$.

Figure 10, 11 Nitzschia interrupta Heid 10. $\times 3500$.

11. $\times 2700$.

Figure 12 Nitzschia marina Grun $\times 2400$. 
PLATE 5
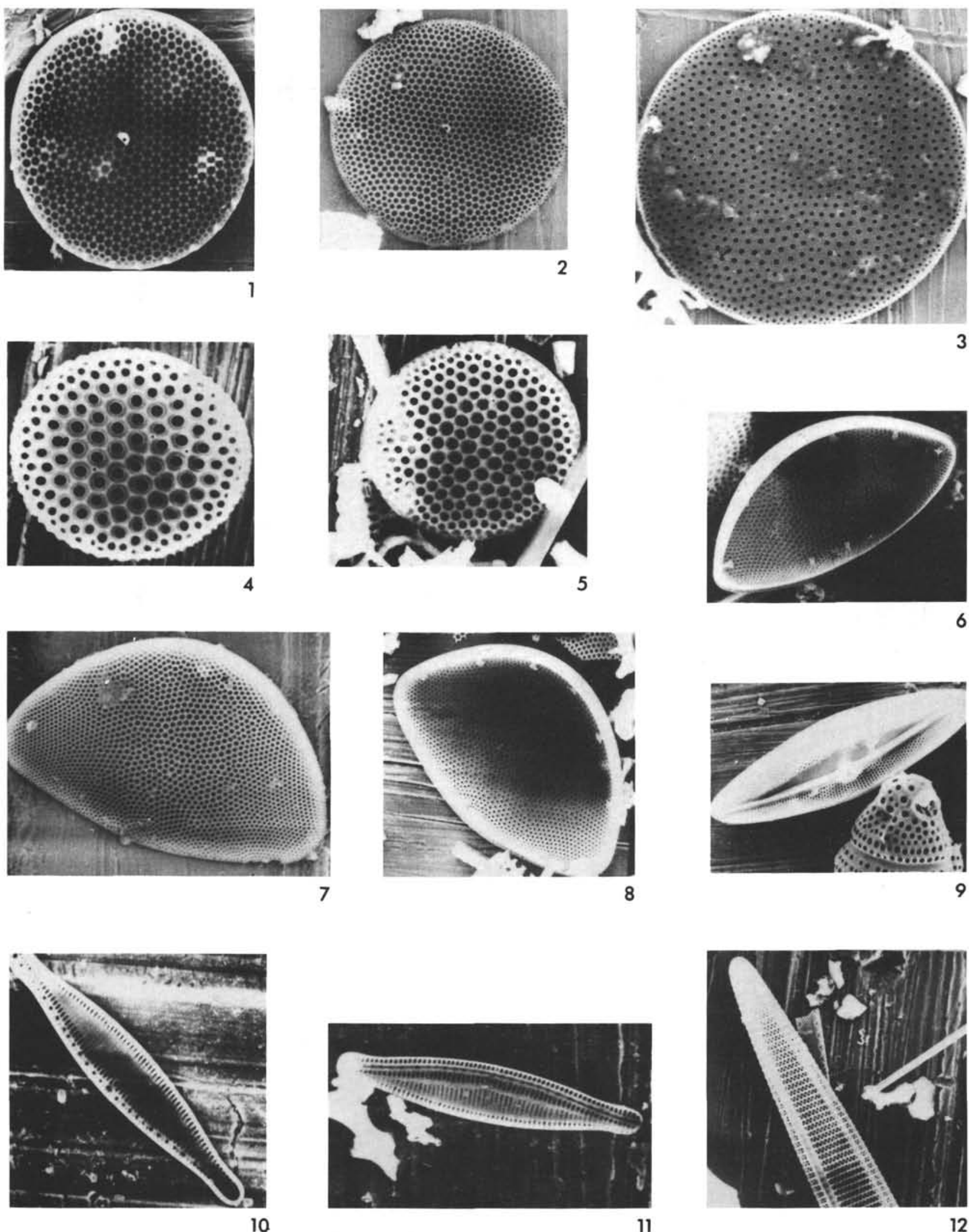


\section{PLATE 6}

Figures 1-6, 9-12, Sample 8-4, 105-107 cm; Figure 7, 8, Sample 14$3,95-97 \mathrm{~cm}$.

Figure $1 \quad$ Nitzschia marina Grun $\times 3100$.

Figure 2-4 Planktoniella sol Schutt 2. $\times 1100$.

3. $\times 2000$.

4. $\times 2000$.

Figure $5 \quad$ Rhizosolenia styliformis Bright $\times 1200$.

Figure 6,7 Roperia tesselata Grun

6. $\times 3700$.

7. $\times 4500$.

Figure $8 \quad$ Roperia tesselata var. ovata Heid $\times 1500$.

Figure 9-11 Thalassionema nitzschioides Grun

9. $\times 1700$.

10. $\times 3900$.

11. $\times 6500$.

Figure $12 \quad$ Thalassiosira oestrupii (Ostf.) Pr.-Lavr $\times 4000$. 
PLATE 6
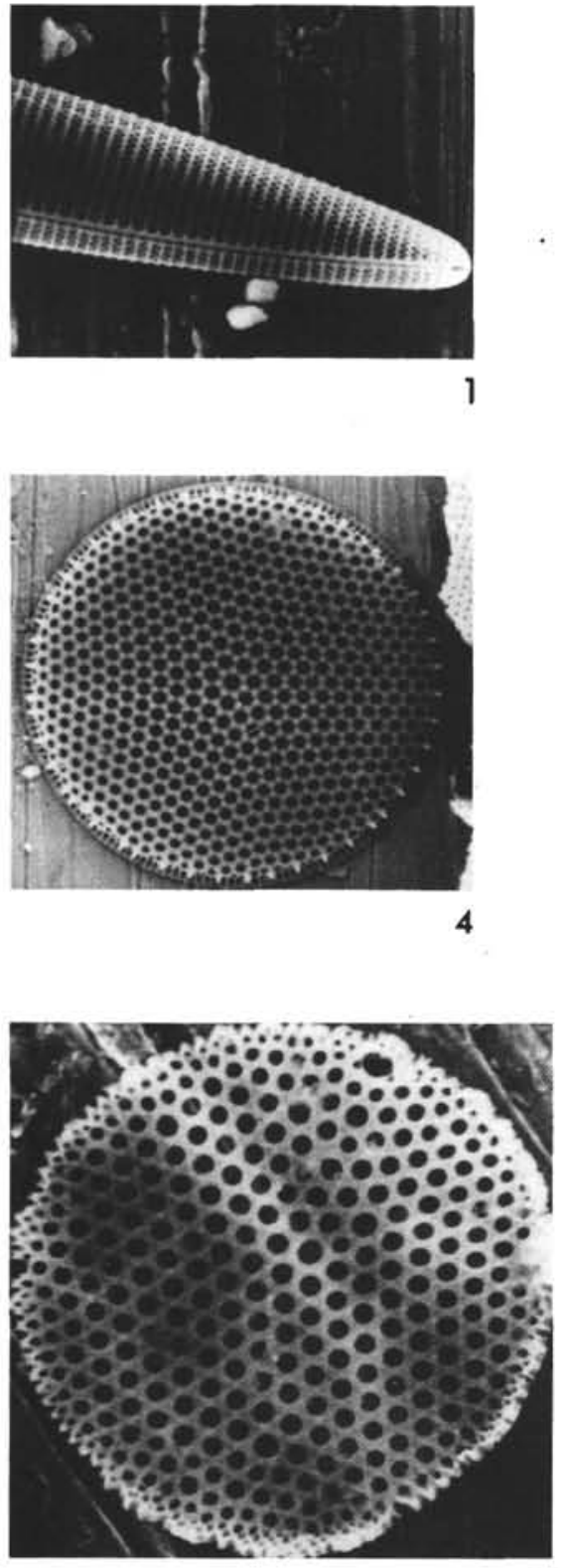

7

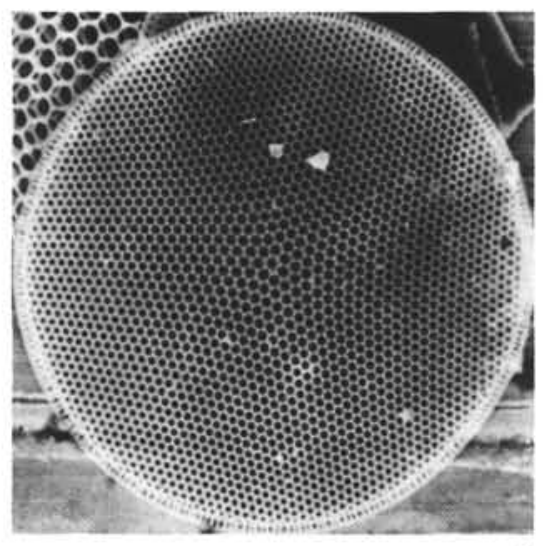

2

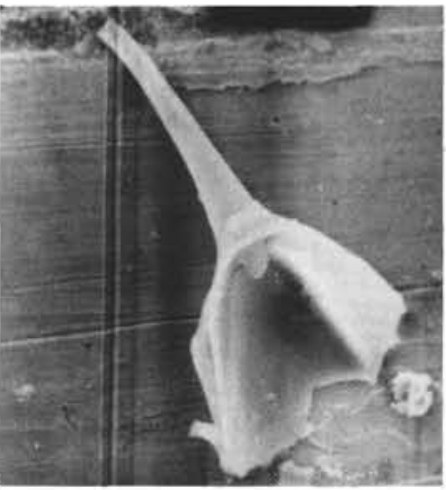

5
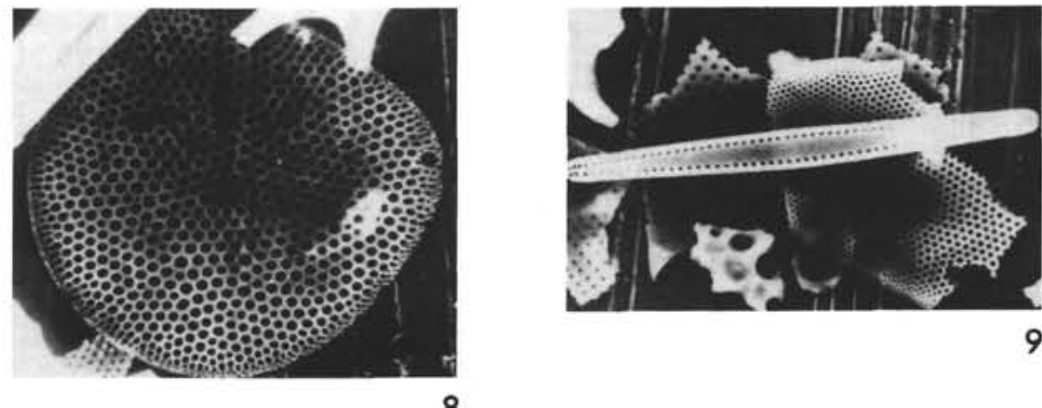
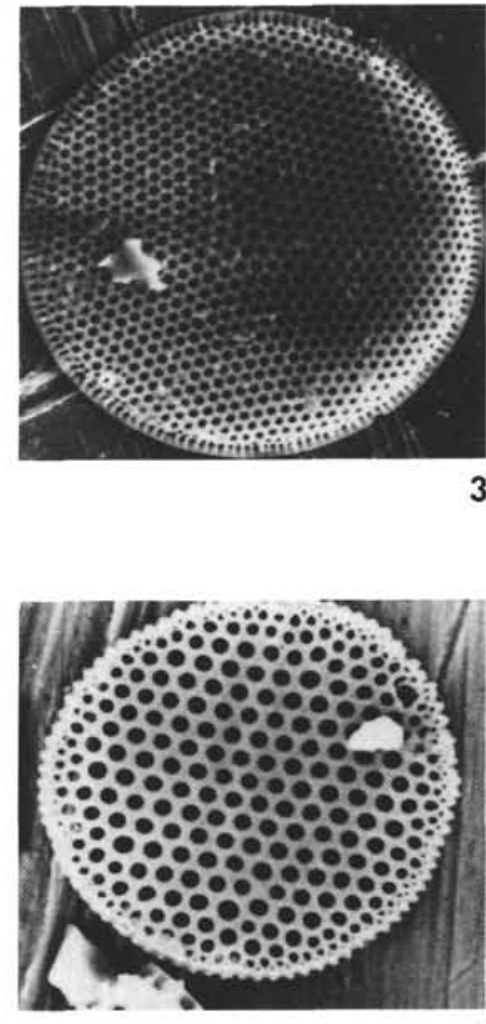

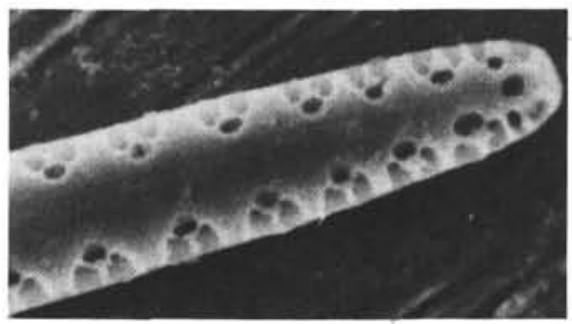

11

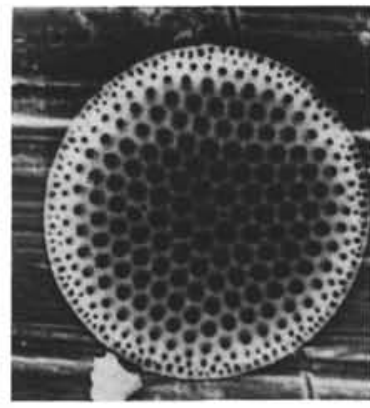

12 


\section{PLATE 7}

Figures 1-3, 6-10, 12, Sample 8-4, 105-107 cm; Figures 4, 5, 11, Sample 14-3, 95-97 cm.

Figure 1-3 Thalassiosira oestrupii (Ostf.) Pr.-Lavr

1. $\times 2500$.

2. $\times 3900$.

3. $\times 3800$.

Figure 4, 5 Thalassiosira oestrupii aff. var. plana Jouse 4. $\times 4000$.

5. $\times 7800$.

Figure 6-9 Thalassiosira $\mathrm{sp}$. A

6. $\times 2500$.

7. $\times 4200$.

8. $\times 3200$.

9. $\times 3200$.

Figure $10 \quad$ Thalassiosira $\mathrm{sp} . \mathrm{C} \times 2000$.

Figure $11 \quad$ Thalassiotrix sp. $\times 4500$.

Figure 12 Triceratium cinnamomeum Grev. $\times 2000$. 


\section{PLATE 7}

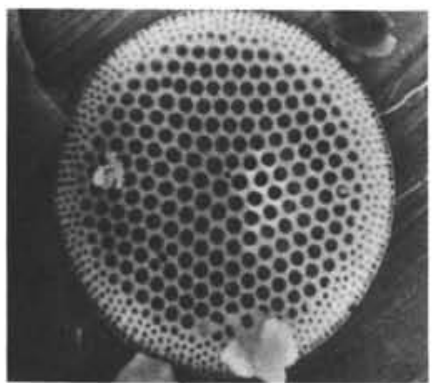

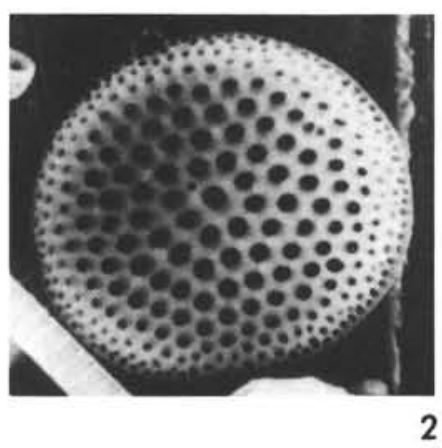

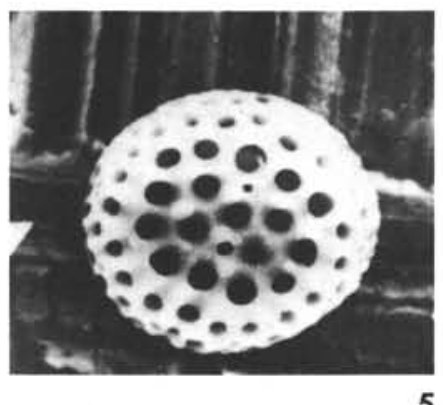

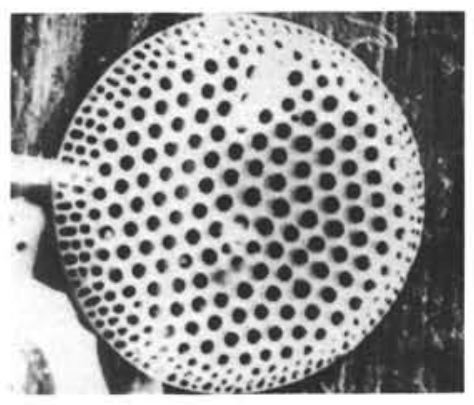
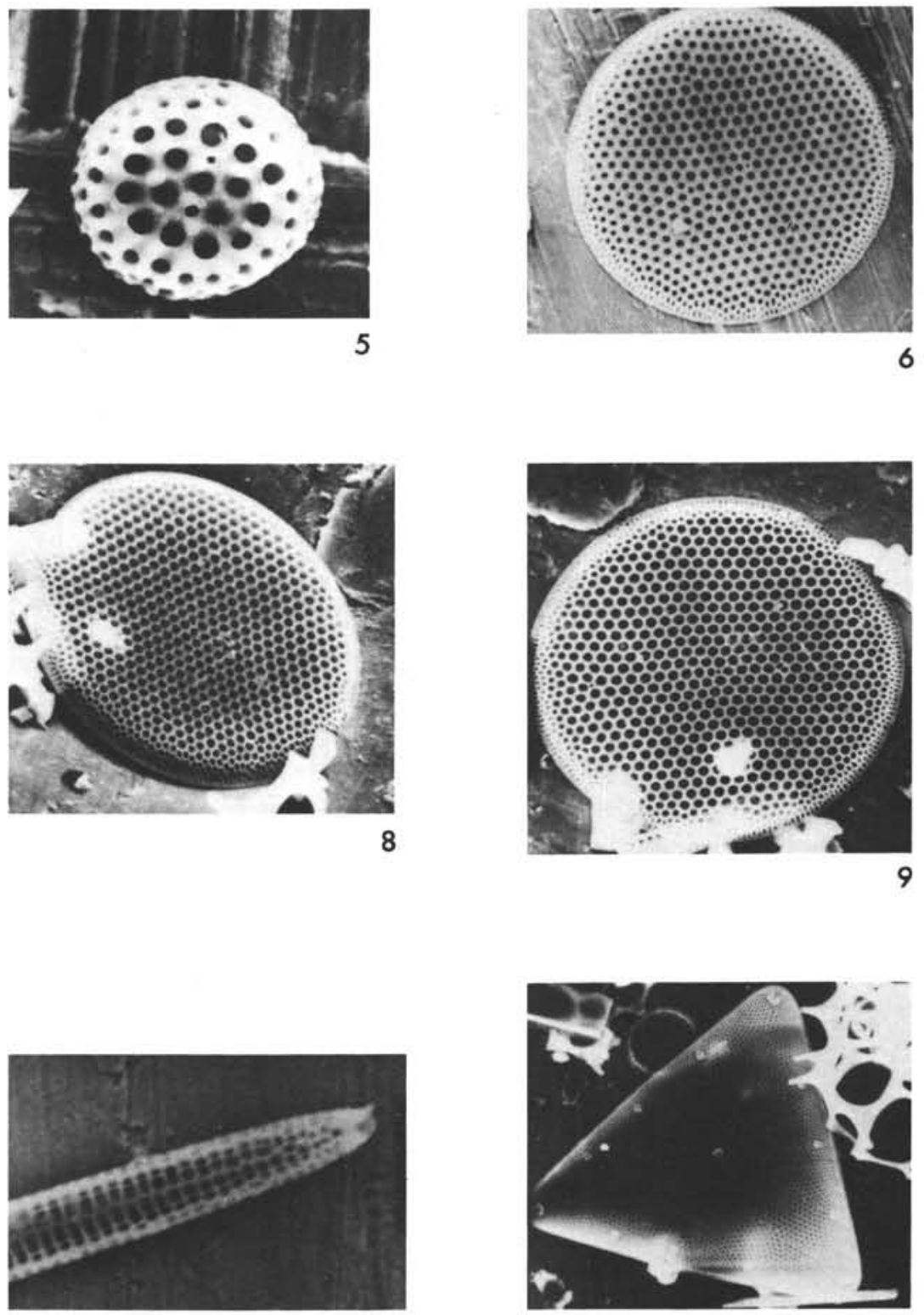

12 